\title{
The effect of starter culture on bacterial profile in soybean tempeh
}

\author{
*Pramudito, T.E., Putri, E.G.A., Paluphi, E. and Yogiara, Y. \\ Faculty of Biotechnology, Atma Jaya Catholic University of Indonesia, Jl. Raya Cisauk Lapan No.70, \\ Tangerang, Banten 15345, Indonesia
}

\begin{abstract}
Article history:
Received: 13 August 2020

Received in revised form: 17

September 2020

Accepted: 9 November 2020

Available Online: 31 January 2021
\end{abstract}

Keywords:

Tempeh,

Starter culture,

Bacterial profile,

qPCR,

Firmicutes,

Gammaproteobacteria

DOI:

https://doi.org/10.26656/fr.2017.5(1).436

\begin{abstract}
The bacterial population in soybean tempeh can be affected by many factors such as hygiene and preparation procedure of the soybean. In this study, we investigate the effect of different tempeh starter culture on the bacterial profile in comparison to other factors. The bacterial profile of five commercial tempeh made with different processing techniques and three samples made with different starter culture were analyzed using quantitative polymerase chain reaction (qPCR). The phylum Verrucomicrobia was only detected in commercial tempeh from unstandardized home-scale industries. Bacteroidetes were present in commercial tempeh and samples made with starter that contains cassavabased materials. Commercial tempeh from standardized medium-scale industries contains fewer total bacteria than those from home-scale industries. The addition of starter culture for tempeh production can increase the number of total bacteria compared to uninoculated soybeans. However, there was no difference in total bacterial amount between starter culture variation. Bacterial profiles of all samples were dominated by Firmicutes except tempeh with the starter culture Cap Jago that is dominated by Gammaproteobacteria. This study showed that although the type of starter culture did not significantly contribute to total bacteria in tempeh, it can influence the bacterial profile of the product on phylum level.
\end{abstract}

\section{Introduction}

Tempeh is an Indonesian traditional food made from the fermentation of soybeans by mold as a starter culture, specifically Rhizopus microsporus var. oligosporus. Fungal growth during fermentation results in a network of mycelia that will bind soybeans into a cohesive cakelike structure. Unlike other soybean-based foods such as tofu, the soybeans in tempeh remain whole resulting in a uniquely textural and nutritional qualities (Shurtleff and Aoyagi, 1985). In general, there are five main steps involved in the tempeh production process, namely cooking of soybeans, soaking in water, dehulling, starter culture inoculation and incubation (Efriwati et al., 2013; Seumahu et al., 2013).

Although mold acts as the main fermenting microorganism in tempeh production, other microorganisms such as bacteria and yeast are also present and grow during production. Some of these bacteria play a major role in tempeh production for example during the soaking process. Endophytic lactic acid bacteria (LAB) in soybeans will grow during the soaking process and acidifying the soybeans thus inhibiting the growth of unwanted microorganisms (Nurdini et al., 2015). Variation of the bacterial population in tempeh is also known to affect the nutritional and sensory characteristic of tempeh. Bacteria can influence the amount of bioactive peptide in tempeh such as bacteriocin produced by LAB (Moreno et al., 2002). Barus et al. (2008) reported how bitter taste in tempeh is affected by the number of proteolytic bacteria in the product. The bacterial activity can also influence the concentration of micronutrient in tempeh such as Citrobacter freundii and Klebsiella pneumoniae that produce vitamin B12 during the fermentation process (Keuth and Bisping, 1994). The bacterial population in tempeh has also been reported to affect the functionality of the product as immunostimulant (Soka et al., 2014).

Considering the role of bacteria in tempeh, modulation of the bacterial population in the product is an approach that can be explored to develop tempeh with desired functionality and sensory profile. One possible way of modulation bacterial population in tempeh is by modifying the production process. For example, the use 
of two-staged cooking process where soybeans are cooked for the second time after the soaking process (Kustyawati, 2009; Seumahu et al., 2013). This modification is aimed to reduce the total number of bacteria in the product to comply with the microbial safety standard set by the Indonesian National Standard (SNI 3144:2015). The two-staged cooking process is often employed by medium to large-scale producer with the standardized procedure, yet it is still an uncommon practice in Indonesia with only one in five producers using the method (Barus et al., 2008). However, the effectiveness of the two-staged cooking method in the modulation of the bacterial population in tempeh is still an ongoing debate especially on what extent it can reduce the number of bacteria (Mulyowidarso et al., 1989; Radita et al., 2018). It is agreed upon that bacterial population in tempeh is influenced by many micro factors that could be difficult to control (Seumahu et al., 2013; Nugraini et al., 2016; Radita et al., 2017).

Another possible approach for the modification of bacterial profile is by using a specific starter culture for fermentation. Tempeh starter culture, or known as ragi tempeh, consists of Rhizopus spores as the main component mixed with carbohydrate derived from the fungal growth medium such as rice flour (Moreno et al., 2002). However, bacteria have been reported to be present in starter culture such as Firmicutes that is detected in commercial starter Raprima that is commonly used by producers in Indonesia (Efriwati et al., 2013; Radita et al., 2018). Several producers also use selfmade traditional starters made from cassava byproduct called onggok starter. It not uncommon for producers to mix commercial starter with their self-made starter to produce tempeh with desirable sensory property (Shurtleff and Aoyagi, 1985; Seumahu et al., 2013). Previous studies reported that the effect of starter culture on bacterial diversity was insignificant compared to the effect of the soaking process (Radita et al., 2017). However, so far there have been no reports investigating the bacterial population between tempeh made with a different starter culture.

In this study, we investigated the factors in the tempeh production process that could influence the bacterial population in tempeh. By using quantitative polymerase chain reaction (qPCR), we profiled the bacterial population from five commercial tempeh made with different production techniques and three lab-made tempeh made with a different starter culture. The aim of this study was to see how far starter culture can influence bacterial population profile in tempeh especially compared to other factors such as sanitation and the cooking process.

\section{Materials and methods}

\subsection{Materials}

Full-fat yellow-seeded soybeans were used for tempeh fermentation and purchased from Pasar Modern Intermoda BSD (Tangerang, West Java). Three starter cultures were used in this experiment, namely the commercial starter Raprima (RP; PT. Aneka Fermentasi Industri, Bandung, Indonesia) and Cap Jago (JG; UD. Jaya Mulya, Kediri, Indonesia) and traditionally manufactured onggok-based starter from cassava cake (OG) acquired from a traditional producer in Cisauk, Banten, Indonesia. Uninoculated soybeans (NF) were used as control. Commercial tempeh samples were purchased from producers in Bogor (EMP, WJB and RTI), Jakarta (JKT) and Surabaya (HNA). EMP, WJB and JKT were categorized as home-scale industry products as they were produced by traditional producers with uncontrolled condition and production process. Additionally, EMP and JKT were produced using onggok-based starter instead of commercial starter Raprima like the other commercial samples. The producers of RTI and HNA have established proper hygiene, controlled production condition and standardized instruments and therefore both samples can be categorized as standardized industry products. The production of RTI and HNA also involves secondary soaking to wash the soybeans. All samples were stored and transported in an icebox prior to analysis. Figure 1 summarizes the different production methods involved in the preparation of each tempeh sample. Pure cultures of Escherichia coli, Staphylococcus aureus and Salmonella enterica ATCC 51741 grown overnight in Luria broth at $37^{\circ} \mathrm{C}$ were used as standards for qPCR.

\subsection{Tempeh fermentation}

Tempeh was prepared based on the procedure described by Kustyawati (2009). Soybeans were soaked overnight in sterile distilled water at room temperature. Afterwards, the beans were dehulled and cooked at 30 mins. The cooked soybeans were cooled to room temperature and divided to four experimental groups, each group weighing $500 \mathrm{~g}$. Starter culture $(0.2 \% \mathrm{w} / \mathrm{w})$ was added to the soybeans and mixed thoroughly. The inoculated soybeans were packed inside a perforated plastic bag and incubated at $30^{\circ} \mathrm{C}$ for $48 \mathrm{hrs}$.

\subsection{Total bacterial DNA isolation}

Total bacterial genomes from tempeh samples were isolated based on the method described by Seumahu et al. (2013) with modifications. Phosphate buffer saline (PBS) $\mathrm{pH} 7.4(150 \mathrm{~mL})$ was added to $50 \mathrm{~g}$ of diced tempeh and the mixture was homogenized. The suspension was centrifuged at $1000 \times g$ for 10 mins. The 


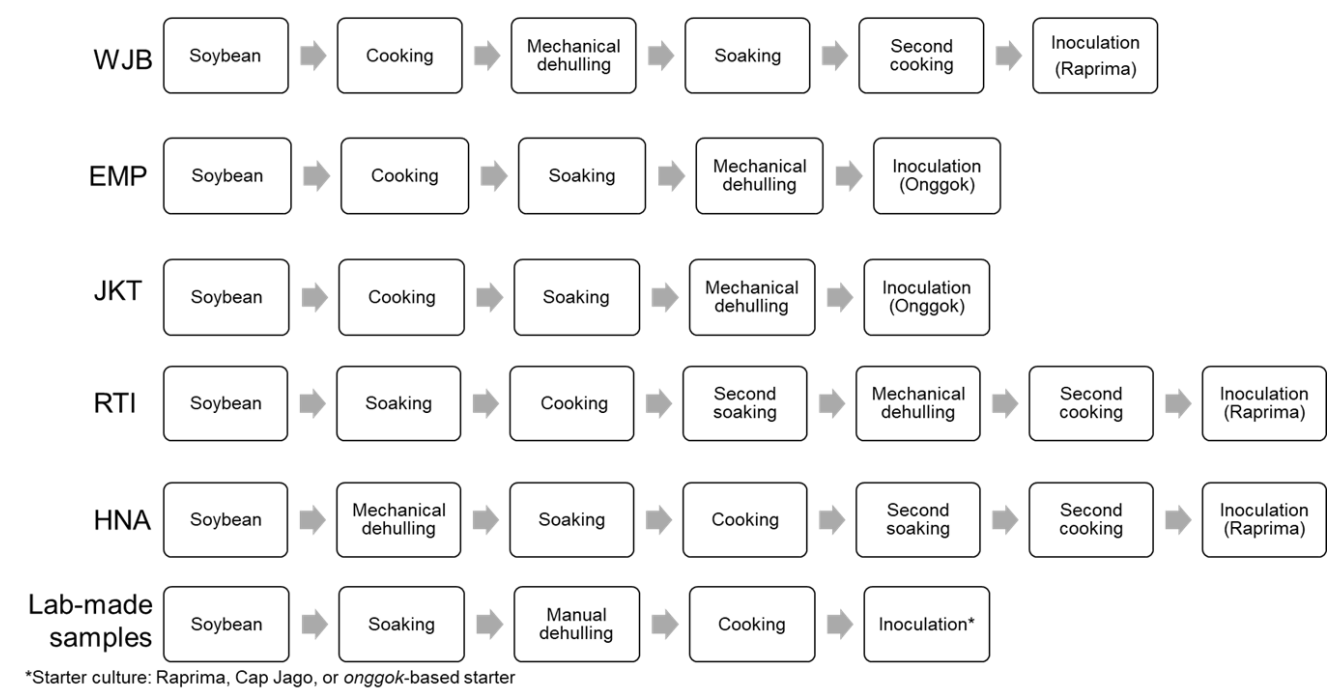

Figure 1. Process flow of different major steps in the manufacturing methods used to produce tempeh samples

supernatant was collected and centrifuged at $10000 \times g$ for 10 mins. Bacterial DNA was extracted from the pellets using ZymoBIOMICSTM DNA Miniprep Kit (Zymo Research, Orange, CA, USA). The genomic DNA isolate was visualized using agarose gel $(1 \% \mathrm{w} / \mathrm{v})$ electrophoresis for confirmation and stored at $-20^{\circ} \mathrm{C}$.

\subsection{Preparation for qPCR standard curve}

Standard curve was constructed from pure culture as described by Soka et al. (2014). Bacterial genomes of $E$. coli, S. aureus and S. enterica ATCC 51741 were isolated using Wizard $\AA$ Genomic DNA Purification Kit (Promega, Madison, WI, USA) each representing total bacteria, Firmicutes and Gammaproteobacteria, respectively. The isolates were amplified using polymerase chain reaction (PCR). The PCR mix consisted of $1 \mu \mathrm{L}$ of DNA template, $1 \mu \mathrm{L}$ of each primer (10 pmol. $\mathrm{LL}^{-1}$ ) (Table 1), $10 \mu \mathrm{L}$ of GoTaq Green ${ }^{\circledR}$ Master Mix (Promega) and nuclease-free water (NFW) for the total volume of $20 \mu \mathrm{L}$. The $\mathrm{PCR}$ reaction conditions were $94^{\circ} \mathrm{C}$ for 3 mins; 30 cycles of $94^{\circ} \mathrm{C}$ for $45 \mathrm{~s}, 55-57^{\circ} \mathrm{C}$ (Table 1) for $1 \mathrm{~min}$ and $72^{\circ} \mathrm{C}$ for $30 \mathrm{~s}$; and $72^{\circ} \mathrm{C}$ for 7 mins. The amplicons were purified using Solg ${ }^{\mathrm{TM}}$ Gel and PCR Purification Kit (SolGent, Daejeon, South Korea). The concentration of the amplicons was determined by spectrophotometry. The amplicons were diluted tenfold to seven standard concentrations between $10^{2}-10^{10}$ DNA copy per reaction.

\subsection{Determination of phyla diversity in tempeh}

Phyla diversity of tempeh samples was determined through the amplification of marker gene associated with specific bacterial phylum using ProFlex ${ }^{\mathrm{TM}}$ PCR System (Thermo Fisher Scientific, Waltham, MA, USA). The isolates were amplified using polymerase chain reaction (PCR). The PCR mix consisted of $1 \mu \mathrm{L}$ of DNA template, $1 \mu \mathrm{L}$ of each primer $\left(10\right.$ pmol. $\left.\mu \mathrm{L}^{-1}\right)$ (Table 1$)$, $10 \mu \mathrm{L}$ of GoTaq Green ${ }^{\circledR}$ Master Mix (Promega) and NFW for the total volume of $20 \mu \mathrm{L}$. The PCR reaction conditions were $94^{\circ} \mathrm{C}$ for $3 \mathrm{~min} ; 30$ cycles of $94^{\circ} \mathrm{C}$ for 45

Table 1. Primers for the amplification of group specific 16s rRNA gene

\begin{tabular}{|c|c|c|c|c|c|}
\hline $\begin{array}{l}\text { Target bacterial } \\
\text { group }\end{array}$ & Primer & Sequence $\left(5^{\prime}-3^{\prime}\right)^{*}$ & Size (bp) & $\begin{array}{c}\text { Annealing } \\
\text { temperature }\left({ }^{\circ} \mathrm{C}\right)\end{array}$ & References \\
\hline \multirow{2}{*}{ Universal bacteria } & Eub338F & ACTCCTACGGGAGGCAGCAG & \multirow{2}{*}{220} & \multirow{2}{*}{57} & \multirow{2}{*}{$\begin{array}{l}\text { Soka et al. } \\
\quad(2014)\end{array}$} \\
\hline & Eub518R & ATTACCGCGGCTGCTGG & & & \\
\hline \multirow{2}{*}{ Firmicutes } & Firm934F & GGAGYATGTGGTTTAATTCGAAGCA & \multirow{2}{*}{126} & \multirow{2}{*}{56.5} & \multirow{2}{*}{$\begin{array}{l}\text { Guo et al. } \\
\text { (2008) }\end{array}$} \\
\hline & Firm1060R & AGCTGACGACAACCATGCAC & & & \\
\hline \multirow{2}{*}{$\begin{array}{c}\text { Gamma } \\
\text { proteobacteria }\end{array}$} & $1080 \gamma \mathrm{F}$ & TCGTCAGCTCGTGTYGTGA & \multirow{2}{*}{122} & \multirow{2}{*}{55} & \multirow{2}{*}{$\begin{array}{l}\text { Karamipour } \\
\text { et al. (2016) }\end{array}$} \\
\hline & $\gamma 1202 \mathrm{R}$ & CGTAAGGGCCATGATG & & & \\
\hline \multirow{2}{*}{ Bacteroidetes } & Bac960F & GTTTAATTCGATGATACGCGAG & \multirow{2}{*}{122} & \multirow{2}{*}{55} & \multirow{2}{*}{$\begin{array}{c}\text { Yang et al. } \\
(2015)\end{array}$} \\
\hline & Bac1100R & TTAASCCGACACCTCACGG & & & \\
\hline \multirow{2}{*}{ Verrucomicrobia } & Ver1165F & TCAKGTCAGTATGGCCCTTAT & \multirow{2}{*}{97} & \multirow{2}{*}{55} & \multirow{2}{*}{$\begin{array}{l}\text { Yang et al. } \\
\text { (2015) }\end{array}$} \\
\hline & Ver1263R & CAGTTTTYAGGATTTCCTCCGCC & & & \\
\hline \multirow{2}{*}{ Tenericutes } & Ten662F & ATGTGTAGCGGTAAAATGCGTAA & \multirow{2}{*}{200} & \multirow{2}{*}{55} & \multirow{2}{*}{$\begin{array}{l}\text { Yang et al. } \\
(2015)\end{array}$} \\
\hline & Ten862R & CMTACTTGCGTACGTACTACT & & & \\
\hline \multirow{2}{*}{ Actinobacteria } & Act664F & TGTAGCGGTGGAATGCGC & \multirow{2}{*}{277} & \multirow{2}{*}{54} & \multirow{2}{*}{$\begin{array}{l}\text { Yang et al. } \\
\quad(2015)\end{array}$} \\
\hline & Act941R & AATTAAGCCACATGCTCCGCT & & & \\
\hline
\end{tabular}


sec, $55-57^{\circ} \mathrm{C}$ (Table 1) for $1 \mathrm{~min}$ and $7{ }^{\circ} \mathrm{C}$ for $30 \mathrm{~s}$; and $72^{\circ} \mathrm{C}$ for 7 mins. The amplicons were visualized using agarose gel $(1.5 \% \mathrm{w} / \mathrm{v})$ electrophoresis and the size of amplicons was determined using the marker GENESTA 100 bp DNA Ladder (Geneall, Lisbon, Portugal). The presence of bacterial phylum was confirmed based on the presence of amplicon band with the correct size. The experiment was carried out as independent replicates.

\subsection{Bacterial quantification with $q P C R$}

The number of total bacteria, Firmicutes and Gammaproteobacteria in tempeh samples was determined based on qPCR analysis. The amplification and detection were performed using iQ5 Multicolor Real -Time PCR Detection System (Bio-Rad, Palo Alto, CA, USA). The PCR reaction mix consisted of $10 \mu \mathrm{L}$ Solg ${ }^{\mathrm{TM}}$ Real-Time PCR Smart Mix (SolGent), $1 \mu \mathrm{L}$ DNA template, $1 \mu \mathrm{L}$ of each primer $\left(10\right.$ pmol. $\left.\mu \mathrm{L}^{-1}\right)$ (Table 1$)$ and NFW for the total volume of $20 \mu \mathrm{L}$. The PCR reaction conditions were $94^{\circ} \mathrm{C}$ for 5 mins; 40 cycles of $94^{\circ} \mathrm{C}$ for $20 \mathrm{~s}, 55-57^{\circ} \mathrm{C}$ (Table 1) for $20 \mathrm{~s}$ and $72^{\circ} \mathrm{C}$ for $50 \mathrm{~s}$; and $72^{\circ} \mathrm{C}$ for $15 \mathrm{~s}$. Each sample was amplified in triplicate.

Amplicons of 16s rRNA gene using group-specific primer were used to generate standard curve. qPCR reading showed linearity between $C_{t}$ value and $\log$ of DNA copy number $\left(R^{2}>0.99\right)$. The concentration of a certain bacterial group in the sample was determined based on the $C_{t}$ value and regression equation generated from the standard curve. Significant statistical differences between the bacterial population of lab-made tempeh samples and uninoculated soybeans (NF) were determined based on paired-samples $t$--test $(p<0.05)$ using SPSS Statistics 22.0 software (IBM, Armonk, NY, USA).

\section{Results and discussion}

\subsection{Physical characteristics of tempeh made with different starter culture}

In this experiment, we prepared tempeh with three different starter culture. The lab-made samples used in this experiment were from the same batch of yellowseeded soybeans and underwent the same production process. Difference between the samples only came up after the addition of starter culture ensuring that variation was solely due to the role of starter culture during fermentation.

RP and JG were made with commercial Raprima and Cap Jago starters respectively and OG was made using cassava-based onggok starter. RP and OG had similar physical characteristic with a solid texture and white mycelia that completely covered the soybeans. SNI
3144:2015 required the following characteristics for commercial tempeh: mycelia that cover space in-between soybeans, the mycelial network that strongly binds the soybeans and the texture of soybeans remains whole and unbroken when tempeh is cut. RP and OG had fulfilled those criteria required by SNI 3144:2015. On the other hand, JG had less mycelium network with the product still having the yellowish color of the soybeans. This was due to the characteristic of Cap Jago starter that has been reported to take a longer time to form a mycelium network resulting in tempeh with less cohesive structure (Amaliyah et al., 2018). However, other than the difference of mycelium density, we did not find other physical difference between the three samples. We also prepared soybeans that undergo the same production process as the tempeh samples but without the addition of starter culture (coded as NF). The soybeans of NF retained their shape and structure but moister and covered with thin slime indicating bacterial growth. These bacteria are most likely a mixture of endophytic bacteria and contaminants from the environment. Several exopolysaccharide-producing bacteria such as Bacillus are known as endophytes in soybeans (Zhang et al., 2012; Lopes et al., 2016). The layer of slime found on $\mathrm{NF}$ was likely exopolysaccharides produced by these bacteria.

\subsection{Diversity of bacterial population in tempeh}

Phylum diversity in tempeh samples was determined based on the amplification of 16s rRNA encoding sequence with six phylum-specific primers. In general, Table 2 shows that the bacterial population in commercial tempeh was more diverse compared to labmade samples. It also showed that Firmicutes, Gammaproteobacteria and Actinobacteria were the phyla that are consistently present in all tempeh samples. The three phyla have been reported to be the dominant bacterial phyla in tempeh with Firmicutes being the most dominant followed with Gammaproteobacteria and Actinobacteria (Radita et al., 2018; Nur et al., 2020). Lactic acid bacteria (LAB) belong the phylum Firmicutes and they are the dominant group of bacteria in tempeh due to their role in the acidification of soybeans during the soaking process (Nurdini et al., 2015). The low $\mathrm{pH}$ of the soybeans could help to inhibit the growth of unwanted microorganisms such as spoilage bacteria. The phylum Gammaproteobacteria is the second most abundant group in tempeh and it is mostly present in the product causing spoilage (Nout et al., 1987; Ashenafi and Busse, 1989). However, several Gammaproteobacteria species such as Klebsiella pneumoniae and Citrobacter freundii play a major role in the production of vitamin B12 in tempeh (Keuth and Bisping, 1994). The phylum Actinobacteria is also 
Table 2. Bacterial phylum profile in tempeh samples based on amplification of phylum-specific 16s rRNA-gene sequence

\begin{tabular}{|c|c|c|c|c|c|c|c|}
\hline \multirow[b]{2}{*}{ Samples } & \multicolumn{7}{|c|}{ Detection by PCR } \\
\hline & $\begin{array}{l}\text { Universal } \\
\text { bacteria }\end{array}$ & Firmicutes & $\begin{array}{c}\text { Gamma } \\
\text { proteobacteria }\end{array}$ & Actinobacteria & Bacteroidetes & Verrucomicrobia & Tenericutes \\
\hline \multicolumn{8}{|c|}{ Commercial tempeh } \\
\hline WJB & + & + & + & + & + & + & - \\
\hline EMP & + & + & + & + & + & + & - \\
\hline $\mathrm{JKT}$ & + & + & + & + & + & - & - \\
\hline RTI & + & + & + & + & + & - & - \\
\hline HNA & + & + & + & + & + & - & - \\
\hline \multicolumn{8}{|c|}{ Lab-made tempeh } \\
\hline $\mathrm{RP}$ & + & + & + & + & - & - & - \\
\hline $\mathrm{JG}$ & + & + & + & + & + & - & - \\
\hline OG & + & + & + & + & + & - & - \\
\hline $\mathrm{NF}$ & + & + & + & + & - & - & - \\
\hline
\end{tabular}

another subdominant group in tempeh but present in less number compared to Firmicutes and Gammaproteobacteria (Radita et al., 2018). Unlike the other two phyla, there have been not many reports on the specific role of Actinobacteria in tempeh. Altogether, bacteria from the three phyla constitute the majority of lipolytic bacteria in tempeh and play a role in flavor production (Nur et al., 2020). Their activity leads to the breakdown of soybean lipid into short chain fatty acid thus influencing the formation of aroma compounds.

Bacteroidetes were present in all commercial samples but in lab-made samples were only detected in JG and OG. Yulandi et al. (2020) studied commercial tempeh that was also used in this experiment, namely EMP and WJB, and reported the abundant presence of Bacteroidetes in those products. However, Radita et al. (2018) reported little presence of Bacteroidetes in the same products indicating the fluctuation of bacterial profile, especially when focusing on minor groups. This might explain why Bacteroidetes were not detected in RP despite being present in JG and OG. The bacterial number could be too low for PCR-based detection. Verrucomicrobia were undetected in lab-made samples and most commercial tempeh except EMP and WJB. As far as we know, there has been no prior reports regarding the presence of Verrucomicrobia in tempeh. Our finding was first to show that the phylum could present in tempeh specifically those made in traditional home-scale industries (EMP and WJB). The species Akkermansia muciniphila, a member of Verrucomicrobia, is an important part of human gut microbiota and plays an important role in the intestinal immune system (Derrien et al., 2011). There have been reports that tempeh consumption could increase the number of $A$. muciniphila in the intestines (Stephanie et al., 2017). Therefore, the detection of Verrucomicrobia in traditional tempeh should not come of a surprise considering that the phylum is known to be promoted by tempeh consumption. The phylum Tenericutes has been reported in fermented foods such as Chinese fermented mung beans (Chao et al., 2013) and Korean fermented anchovy sauce (Jung et al., 2016) but they have not been reported to be found in tempeh. This report also showed the absence of Tenericutes in all commercial and labmade samples.

The composition of starter culture could also explain the less diverse bacterial profile in RP compared to OG and JG. Raprima consisted of a mixture of rice flour and fungal spores. The mixture was processed in a standardized and hygienic condition thus minimizing bacterial contamination (Bintari et al., 2009). Cap Jago contained the same materials as Raprima but with the addition of tapioca flour derived from cassava (Amaliyah et al., 2018). Bacteroidetes have been reported to be associated with cassava and its derivates (Gao et al., 2012; Sarr et al., 2017) which explain its presence in JG. OG was prepared using onggok-based starter, which is a traditional starter made from cassava press cake, a byproduct of tapioca production. In the production of onggok--based starter, the culture of Rhizopus sp. is mixed with cassava cake and warm water before the mixture is dried (Owens, 2014; Tamam et al., 2019). This traditional process could result in more bacterial contamination compared to commercial starters such as Raprima. From comparing the composition of the three starters, it would be tempting to hypothesize that the presence of cassava-based material in starter culture could promote the growth of Bacteroidetes. However, a further investigation would be necessary to see whether the composition of starter culture could be used for the modulation of bacterial profile in tempeh.

\subsection{Starter culture provided minimal contribution to the number of total bacteria in tempeh}

The number of total bacteria in tempeh was determined based on qPCR of universal 16s rRNA encoding gene. Bacterial number was expressed as the logarithmic value of copy numbers per g sample $(\log Q \mathrm{~g}$ 
$\left.{ }^{-1}\right)$. Figure 2 shows the varying degree of total bacteria in commercial tempeh. WJB had the highest number of total bacteria at $6.22 \pm 0.05 \log \mathrm{Q} \mathrm{g}^{-1}$ while the lowest was seen in HNA at $4.23 \pm 0.08 \log \mathrm{Q} \mathrm{g}^{-1}$. Samples collected from home-scale industry (WJB, EMP and JKT) had higher number of total bacteria compared to samples from standardized industry (RTI and HNA). The later production process also involves secondary soaking step to wash the soybeans. This implied that production condition and general hygiene play a major role in determining the number of total bacteria in tempeh. On the other hand, second-stage cooking and starter culture might not significantly influence total bacterial population. WJB was produced using Raprima starter culture and involved two-stage cooking, like RTI and HNA, but its number of total bacteria was higher than EMP and JKT. EMP and JKT were produced with the same procedure but the total number of bacteria in EMP was higher than JKT. Radita et al. (2018) reported that two-stage cooking could decrease the total number of bacteria, but our finding seemed to indicate that this influence could be mitigated by poor hygiene of the production facility. Overall, our data support other reports that emphasized the effect of hygiene and sanitation in tempeh industry on total bacterial population (Mulyowidarso et al., 1989; Efriwati et al., 2013; Nur et al., 2020).

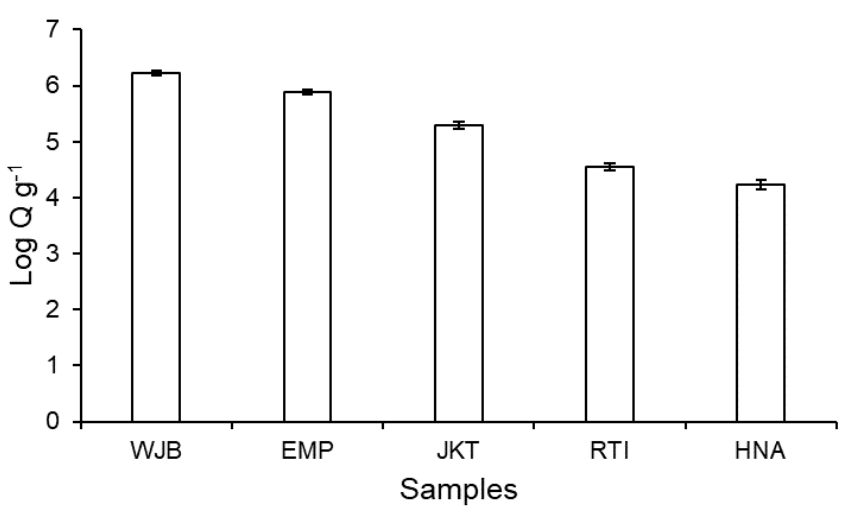

Figure 2. Total bacterial number in five commercial tempeh based on qPCR. Bars represent mean values (expressed as log copy number per gram total weight of the sample $\log \mathrm{Q} \mathrm{g}^{-1}$ ) from three replicates of measurement. Error bars represent the standard error of mean.

Unlike commercial tempeh, total bacteria in labmade tempeh were less varied between one and another as shown in Figure 3. OG had the highest total number of bacteria at $6.36 \pm 0.11 \log \mathrm{Q} \mathrm{g}^{-1}$ and JG was the lowest at $5.81 \pm 0.05 \log \mathrm{Q} \mathrm{g}^{-1}$. This indicated that the type of starter culture used for fermentation did not influence the total number of bacteria in the product. However, the number of total bacteria in all three lab-made tempeh was statistically higher $(p<0.05)$ than fermented soybeans treated without the addition of starter culture $(\mathrm{NF})$ at $5.04 \pm 0.03 \log \mathrm{Q} \mathrm{g}^{-1}$. This finding showed that the addition of starter culture contributed to the total number of bacteria although it did not matter which type of starter culture that is being added. Radita et al. (2017) also reported the presence of a significant number of bacteria in commercial starter culture which might explain how the addition of starter culture would increase the number of total bacteria. It should also be noted that the number of total bacteria of lab-made tempeh in this experiment was higher than commercial tempeh. This could be due to the production process of lab-made tempeh that involved one-stage cooking similar to that of EMP and manual dehulling of the soybeans. The higher number of total bacteria in OG was related to the production method of onggok--based starter. The starter production did not involve sterilization step of cassava cake and Rhizopus fungal spore mixture. Instead, the mixture was only washed with warm water thus providing an ideal condition for bacterial proliferation (Owens, 2014; Tamam et al., 2019).

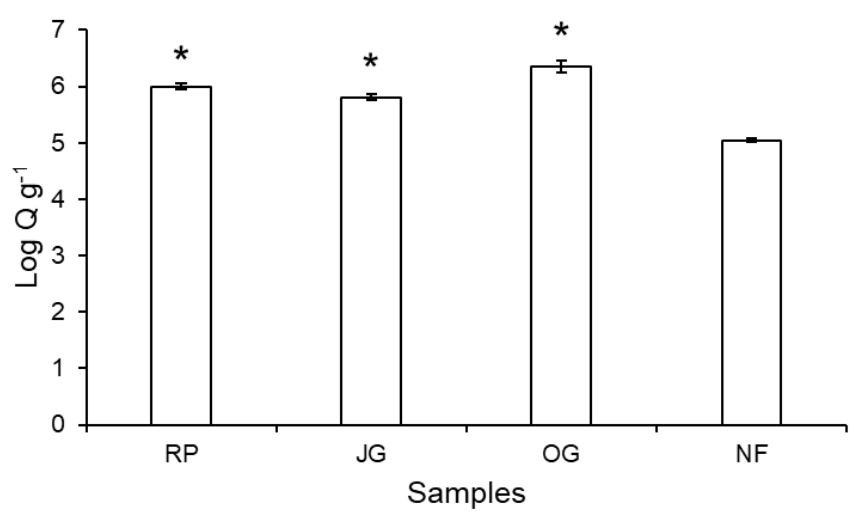

Figure 3. Total bacterial number in lab-made tempeh samples based on qPCR. RP: tempeh fermented with commercial starter Raprima; JG: tempeh fermented with commercial starter Cap Jago; OG: tempeh fermented with traditional cassava-based onggok starter; NF: uninoculated cooked soybeans. Bars represent mean values (expressed as log copy number per gram total weight of the sample $\log \mathrm{Q} \mathrm{g}^{-1}$ ) from three replicates of measurement. Error bars represent the standard error of mean. Asterisk indicates significant difference $(p<0.05)$ between sample and NF.

\subsection{Starter culture can influence bacterial phylum profile of soybean tempeh}

In this study, we focused on the ratio of Firmicutes and Gammaproteobacteria considering both phyla make up the majority of the bacterial population in tempeh. The number of Firmicutes and Gammaproteobacteria in tempeh samples was determined based on qPCR with primers that amplify regions of 16s rRNA encoding gene that are specific to both phyla. Figure 4A shows that the ratio of Gammaproteobacteria and Firmicutes in commercial tempeh did not differ between one another. Firmicutes dominated the bacterial profile with at least $80 \%$ share. The dominance of Firmicutes could be said 
to be unaffected by the variation of the production method of commercial tempeh. It should be noted that tempeh produced by standardized industries (RTI and HNA) showed the lower share of Firmicutes at around $80 \%$ compared to tempeh from home-scale industries (WJB, EMP and JKT) at around 90\%. The share of Firmicutes was also slightly lower in WJB than JKT and EMP. The result seemed to indicate that the two-stage cooking process used in RTI, HNA and WJB can contribute to the higher proportion of Gammaproteobacteria than one-stage cooking process.

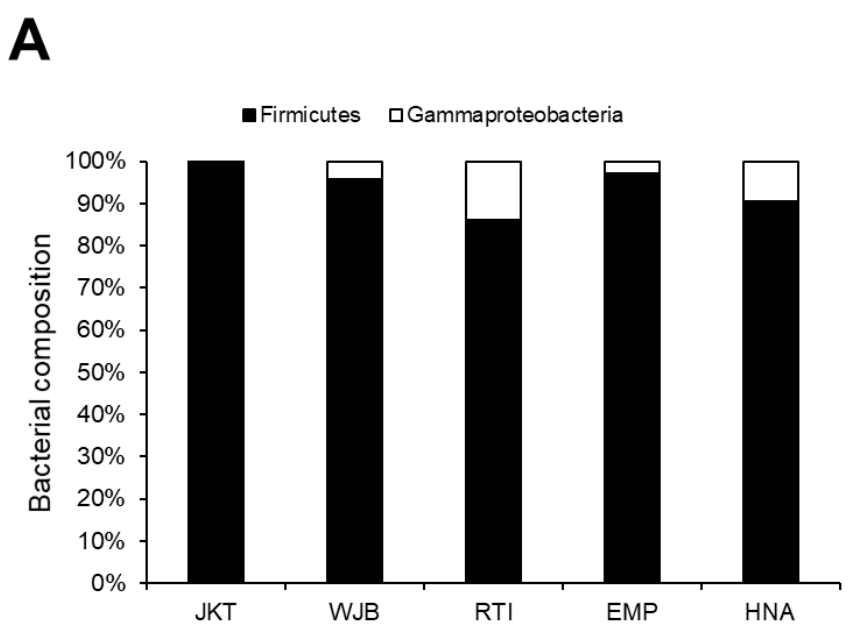

B

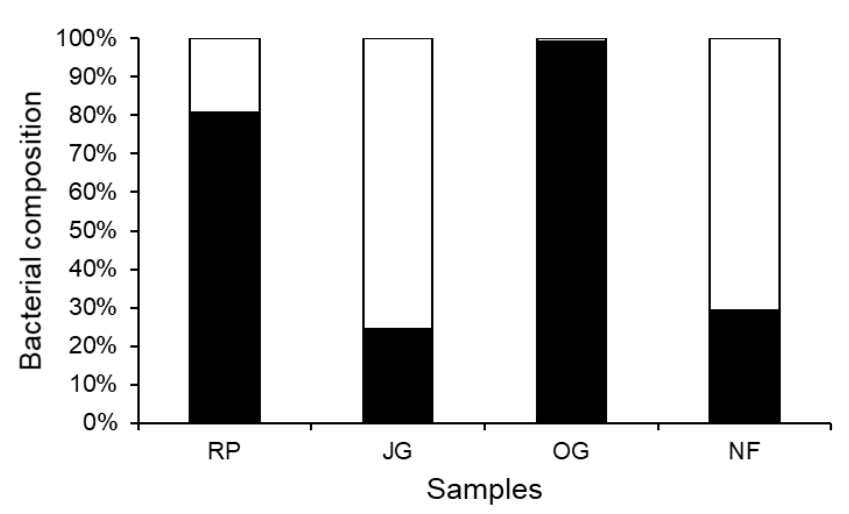

Figure 4. Ratio of Firmicutes and Gammaproteobacteria in A) commercial samples (B) lab-made tempeh made with different starter culture RP (JG and $\mathrm{OG}$ ) and uninoculated soybeans.

The dominance of Firmicutes in JKT and EMP could also be explained by the onggok-based starter used in their production. The same dominance of profile could also be seen in lab-made OG that used onggok-based starter (see Figure 4B). The abundance of Firmicutes in tempeh made with onggok-based starter could be due to the presence of endospore-forming bacteria such as those from the genus Bacillus. B. subtilis has been detected in cassava industry byproducts such as wastewater and processing effluent (Nitschke and Pastore, 2004; Nitschke and Pastore, 2006). Melo et al. (2009) reported the presence of $B$. pumilus as an endophyte in cassava plants. These bacteria can form endospores that can withstand the drying process involved in onggok production. The bacterial endospores could be inoculated onto the soybeans along with Rhizopus spores thus leading to an increase in the number of Firmicutes.

Figure 4B indicates that different starter culture could affect bacterial composition in tempeh. RP and OG showed a similar profile with that of commercial samples with Firmicutes making up $80 \%$ of the ratio. This result matched our expectation considering that both starter cultures were also used to produce commercial samples (WJB, RTI and HNA) studied in this report. However, the profile of tempeh made with Cap Jago starter (JG) was dominated Gammaproteobacteria at around $75 \%$. The bacterial profile of JG did not follow the same preestablished knowledge of Firmicutes domination in tempeh as shown by commercial samples and lab-made RP and OG. In fact, the bacterial profile of JG was more similar to NF that was also dominated by Gammaproteobacteria. The bacterial profile of NF was as expected considering that the bacterial growth on the uninoculated soybeans could be more due to spoilage microorganisms that mostly belong to the phylum Gammaproteobacteria. The dominance of Gammaproteobacteria in NF is supported by Radita et al. (2017) that reported that more than $70 \%$ of bacterial composition in uninoculated soybeans consisted of bacteria from the phylum Proteobacteria.

The similarity of bacterial profile in JG with NF showed that the starter culture Cap Jago might promote the growth of Gammaproteobacteria, possibly spoilage microorganism, better than Firmicutes. This could be explained by the slow growth of Rhizopus in Cap Jago starter. In other starters like Raprima and onggok-based starter, fungal growth leads to competition between bacteria and Rhizopus even in the early stage of fermentation. Moreover, it has been reported that Rhizopus oligosporus can produce antibacterial secondary metabolite when grown in soybeans or soybased medium (McCue et al., 2004). This could further contribute to the inhibition of bacterial growth during tempeh fermentation. The slow growth of Rhizopus in Cap Jago starter causes bacterial growth to be uninhibited, especially spoilage bacteria. Gammaproteobacteria such as E. coli and Salmonella tend to have shorter doubling time than Firmicutes (Gibson et al., 2018) which allows them easily to overtake the growth of the later when grown in a condition without competition from fungi.

As far as we know, we are the first to report tempeh (JG) with the bacterial profile that is dominated by another bacterial group than Firmicutes. The starter 
culture Cap Jago is a regional product from Kediri, East Java that is more commonly utilized by producers around that specific area. At the time of the writing of this article, there had been very limited reports on the microbiological profile of Cap Jago and therefore we hope this finding would spark an interest in further investigation of underreported starter culture like Cap Jago.

Bacterial population profile in tempeh can affect various characteristics of the product, but starter culture is rarely considered as a factor that might also influence the bacterial population in tempeh. Radita et al. (2017) reported that bacterial population is more affected by the soaking process compared to the application of starter culture. This was based on how the bacterial profile in tempeh was very similar to the bacterial profile of water used for soaking while they did not find any similarity with the starter culture. It should be considered that they did not investigate the bacterial profile between tempeh made with different starter culture. So far, our finding was the first that reported how the variation of starter culture might be an important variable that can alter bacterial composition in tempeh. Considering how bacterial population can influence the characteristic and nutritional content in tempeh, optimization of starter culture might be a possible alternative approach for the development of tempeh product with certain functionality.

\section{Conclusion}

We found that the type of starter culture can influence the bacterial phylum profile in soybean tempeh. This influence can be seen in the difference of phylum diversity and the ratio of Firmicutes and Gammaproteobacteria populations between lab-made tempeh fermented with different starter cultures. On the other hand, the influence of starter culture on the total bacterial population in soybean tempeh was negligible especially compared to other parameters such as soybeans cooking method and hygiene of the facility. Nevertheless, we found that the type of starter culture is not a factor that simply can be ignored when it comes to its effect on bacterial population soybean tempeh. Our report only focused on phylum diversity and ratio of two dominant phyla, Firmicutes and Gammaproteobacteria. More information could be discovered through in-depth population study focusing on the lower level of bacterial taxonomy such as on class and family level.

\section{Conflict of interest}

The authors declare no conflict of interest.

\section{Acknowledgments}

This work was funded by Science and Technology Research Grant from Indonesia Toray Science Foundation.

\section{References}

Amaliyah, F., Wisaniyasa, N.W. and Yusasrini, N.L.A. (2018). Pemanfaatan Bekatul Jagung dan Ragi Cap Jago untuk Pembuatan Ragi Tempe dan Karakteristik Tempe yang Dihasilkan. Jurnal Ilmiah Teknologi Pertanian Agrotechno, 2(2), 231-237.

Ashenafi, M. and Busse, M. (1989). Inhibitory Effect of Lactobacillus plantarum on Salmonella infantis, Enterobacter aerogenes and Escherichia coli during Tempeh Fermentation. Journal of Food Protection, 52(3), 169-172. https://doi.org/10.4315/0362-028X52.3.169

Barus, T., Suwanto, A., Wahyudi, A.T. and Wijaya, H. (2008). Role of Bacteria in Tempe Bitter Taste Formation: Microbiological and Molecular Biological Analysis Based on 16S rRNA Gene. Microbiology Indonesia, 2(1), 4. https:// doi.org/10.5454/mi.2.1.4

Bintari, S.H., Anisa Dyah, P., Veronika Eka, J. and Rivana Citra, R. (2009). Efek Inokulasi Bakteri Micrococcus luteus Terhadap Pertumbuhan Jamur Benang dan Kandungan Isoflavon pada Proses Pengolahan Tempe (Effect Inoculation of Micrococcus luteus to Growth of Mold and Content Isoflavone at Tempe Processing). Biosaintifika: Journal of Biology and Biology Education, 1(1), 43. [In Bahasa Indonesia].

Chao, S.-H., Huang, H.-Y., Chang, C.-H., Yang, C.-H., Cheng, W.-S., Kang, Y.-H., Watanabi, K. and Tsai, Y.-C. (2013). Microbial Diversity Analysis of Fermented Mung Beans (Lu-Doh-Huang) by Using Pyrosequencing and Culture Methods. PLOS ONE, 8 (5), e63816. https://doi.org/10.1371/ journal.pone.0063816

Derrien, M., van Baarlen, P., Hooiveld, G., Norin, E., Muller, M. and de Vos, W. (2011). Modulation of Mucosal Immune Response, Tolerance, and Proliferation in Mice Colonized by the MucinDegrader Akkermansia muciniphila. Frontiers in Microbiology, 2, e00166. https://doi.org/10.3389/ fmicb.2011.00166

Efriwati, Suwanto, A., Rahayu, G. and Nuraida, L. (2013). Population Dynamics of Yeasts and Lactic Acid Bacteria (LAB) During Tempeh Production. HAYATI Journal of Biosciences, 20(2), 57-64. https://doi.org/10.4308/hjb.20.2.57

Gao, R., Cao, Y., Yuan, X., Zhu, W., Wang, X. and Cui, 
Z. (2012). Microbial diversity in a full-scale anaerobic reactor treating high concentration organic cassava wastewater. African Journal of Biotechnology, 11(24), 6494-6500. https:// doi.org/10.5897/AJB11.3142

Gibson, B., Wilson, D.J., Feil, E. and Eyre-Walker, A. (2018). The distribution of bacterial doubling times in the wild. Proceedings of the Royal Society B: Biological Sciences, 285, 20180789. https:// doi.org/10.1098/rspb.2018.0789

Guo, X., Xia, X., Tang, R., Zhou, J., Zhao, H. and Wang, K. (2008). Development of a real-time PCR method for Firmicutes and Bacteroidetes in faeces and its application to quantify intestinal population of obese and lean pigs. Letters in Applied Microbiology, 47 (5), 367-373. https://doi.org/10.1111/j.1472765X.2008.02408.x

Jung, J.Y., Lee, H.J., Chun, B.H. and Jeon, C.O. (2016). Effects of Temperature on Bacterial Communities and Metabolites during Fermentation of MyeolchiAekjeot, a Traditional Korean Fermented Anchovy Sauce. PLOS ONE, 11(3), e0151351. https:// doi.org/10.1371/journal.pone.0151351

Karamipour, N., Mehrabadi, M. and Fathipour, Y. (2016). Gammaproteobacteria as essential primary symbionts in the striped shield bug, Graphosoma lineatum (Hemiptera: Pentatomidae). Scientific Reports, 6, 33168. https://doi.org/10.1038/srep33168

Keuth, S. and Bisping, B. (1994). Vitamin B12 production by Citrobacter freundii or Klebsiella pneumoniae during tempeh fermentation and proof of enterotoxin absence by PCR. Applied and Environmental Microbiology, 60(5), 1495-1499. https://doi.org/10.1128/AEM.60.5.1495-1499.1994

Kustyawati, M. (2009). Kajian Peran Yeast dalam Pembuatan Tempe. Agritech, 29(2), 64-70. [In Bahasa Indonesia].

Lopes, K.B.de A., Carpentieri-Pipolo, V., Oro, T.H., Pagliosa, E.S. and Degrassi, G. (2016). Culturable endophytic bacterial communities associated with field-grown soybean. Journal of Applied Microbiology, 120(3), 740-755. https:// doi.org/10.1111/jam.13046

McCue, P., Lin, Y.-T., Labbe, R.G. and Shetty, K. (2004). Sprouting and Solid-State Bioprocessing by Rhizopus oligosporus Increase the In Vitro Antibacterial Activity of Aqueous Soybean Extracts Against Helicobacter pylori. Food Biotechnology, 18 (2), 229-249. https://doi.org/10.1081/FBT200025669

Melo, F.M.P.D., Fiore, M.F., Moraes, L.A.B.D., SilvaStenico, M.E., Scramin, S., Teixeira, M.D.A. and
Melo, I.S.de. (2009). Antifungal compound produced by the cassava endophyte Bacillus pumilus MAIIIM4a. Scientia Agricola, 66(5), 583-592. https://doi.org/10.1590/S0103-90162009000500002

Moreno, M.R.F., Leisner, J.J., Tee, L.K., Ley, C., Radu, S., Rusul, G., Vancanneyt, M. and De Vuyst, L. (2002). Microbial analysis of Malaysian tempeh, and characterization of two bacteriocins produced by isolates of Enterococcus faecium. Journal of Applied Microbiology, 92(1), 147-157. https:// doi.org/10.1046/j.1365-2672.2002.01509.x

Mulyowidarso, R.K., Fleet, G.H. and Buckle, K.A. (1989). The microbial ecology of soybean soaking for tempe production. International Journal of Food Microbiology, 8(1), 35-46. https:// doi.org/10.1016/0168-1605(89)90078-0

Nitschke, M. and Pastore, G.M. (2004). Biosurfactant production by Bacillus subtilis using cassavaprocessing effluent. Applied Biochemistry and Biotechnology, 112(3), 163-172. https:// doi.org/10.1385/ABAB:112:3:163

Nitschke, M. and Pastore, G.M. (2006). Production and properties of a surfactant obtained from Bacillus subtilis grown on cassava wastewater. Bioresource Technology, 97(2), 336-341. https://doi.org/10.1016/ j.biortech.2005.02.044

Nout, M.J.R., Beernink, G. and Bonants-van Laarhoven, T.M.G. (1987). Growth of Bacillus cereus in soyabean tempeh. International Journal of Food Microbiology, 4(4), 293-301. https:// doi.org/10.1016/0168-1605(87)90004-3

Nugraini, A.R., Bintari, S.H. and Mustikaningtyas, D. (2016). Analisis proses pembuatan tempe melalui cara produksi higienis dan pendekatan molekuler. Life Science, 5(1), 9-17.

Nur, N., Meryandini, A., Suhartono, M.T. and Suwanto, A. (2020). Lipolytic bacteria and the dynamics of flavor production in Indonesian tempeh. Biodiversitas Journal of Biological Diversity, 21(8), 3818-3825. https://doi.org/10.13057/biodiv/d210850

Nurdini, A.L., Nuraida, L., Suwanto, A. and Suliantari. (2015). Microbial growth dynamics during tempe fermentation in two different home industries. International Food Research Journal, 22(4), 16681674.

Owens, J.D. (2014). Indigenous Fermented Foods of Southeast Asia. 1st ed. Boca Raton: CRC Press. https://doi.org/10.1201/b17835

Radita, R., Suwanto, A., Kurosawa, N., Wahyudi, A.T. and Rusmana, I. (2017). Metagenome analysis of tempeh production: Where did the bacterial community in tempeh come from? Malaysian 
Journal of Microbiology, 13(4), 280-288. https:// doi.org/10.21161/mjm.101417

Radita, R., Suwanto, A., Wahyudi, A.T. and Rusmana, I. (2018). Firmicutes is the predominant bacteria in tempeh. International Food Research Journal, 25(6), 2313-2320.

Sarr, P.S., Sugiyama, A., Begoude, A.D.B., Yazaki, K., Araki, S. and Nawata, E. (2017). Molecular assessment of the bacterial community associated with Cassava (Manihot esculenta Crantz) cultivation in Cameroon. Microbiological Research, 197, 2228. https://doi.org/10.1016/j.micres.2016.12.011

Seumahu, C.A., Suwanto, A., Rusmana, I. and Solihin, D.D. (2013). Bacterial and Fungal Communities in Tempeh as Reveal by Amplified Ribosomal Intergenic Sequence Analysis. HAYATI Journal of Biosciences, 20(2), 65-71. https://doi.org/10.4308/ hjb.20.2.65

Shurtleff, W. and Aoyagi, A. (1985). History of Tempeh, a Fermented Soyfood from Indonesia. 1st ed. Lafayette: Soyfoods Center.

Soka, S., Suwanto, A., Sajuthi, D. and Rusmana, I. (2014). Impact of Tempeh Supplementation on Gut Microbiota Composition in Sprague-Dawley Rats. Research Journal of Microbiology, 9(4), 189-198. https://doi.org/10.3923/jm.2014.189.198

Stephanie, S., Ratih, N.K., Soka, S. and Suwanto, A. (2017). Effect of Tempeh Supplementation on the Profiles of Human Intestinal Immune System and Gut Microbiota. Microbiology Indonesia, 11(1), 2. https://doi.org/10.5454/mi.11.1.2

Tamam, B., Syah, D., Suhartono, M.T., Kusuma, W.A., Tachibana, S. and Lioe, H.N. (2019). Proteomic study of bioactive peptides from tempe. Journal of Bioscience and Bioengineering, 128(2), 241-248. https://doi.org/10.1016/j.jbiosc.2019.01.019

Yang, Y.-W., Chen, M.-K., Yang, B.-Y., Huang, X.-J., Zhang, X.-R., He, L.-Q., Zhang, J. and Hua, Z.-C. (2015). Use of 16S rRNA Gene-Targeted GroupSpecific Primers for Real-Time PCR Analysis of Predominant Bacteria in Mouse Feces. Applied and Environmental Microbiology, 81(19), 6749-6756. https://doi.org/10.1128/AEM.01906-15

Yulandi, A., Waturangi, D.E., Wahyudi, A.T. and Suwanto, A. (2020). Shotgun Metagenomic Analysis Reveals New Insights on Bacterial Community Profiles in Tempeh. bioRxiv, 2020, 988444. https:// doi.org/10.1101/2020.03.12.988444

Zhang, Y.Z., Chen, W.F., Li, M., Sui, X.H., Liu, H.-C., Zhang, X.X. and Chen, W.X. (2012). Bacillus endoradicis sp. nov., an endophytic bacterium isolated from soybean root. International Journal of
Systematic and Evolutionary Microbiology, 62(2), 359-363. https://doi.org/10.1099/ijs.0.028936-0 